\title{
OPEN Enzymes of an alternative pathway of glucose metabolism in obligate methanotrophs
}

\author{
Olga N. Rozova ${ }^{1}$, Galina A. Ekimova ${ }^{1}$, Nikolai V. Molochkov ${ }^{2}$, Alexander S. Reshetnikov ${ }^{1}$, \\ Valentina N. Khmelenina ${ }^{1 \bowtie}$ \& Ildar I. Mustakhimov ${ }^{1}$
}

Aerobic methanotrophic bacteria utilize methane as a growth substrate but are unable to grow on any sugars. In this study we have shown that two obligate methanotrophs, Methylotuvimicrobium alcaliphilum $20 \mathrm{Z}$ and Methylobacter luteus IMV-B-3098, possess functional glucose dehydrogenase (GDH) and gluconate kinase (GntK). The recombinant GDHs from both methanotrophs were homotetrameric and strongly specific for glucose preferring NAD+ over NADP+. GDH from Mtm. alcaliphilum was most active at $\mathrm{pH} 10\left(V_{\max }=95 \mathrm{U} / \mathrm{mg}\right.$ protein $)$ and demonstrated very high $K_{\mathrm{m}}$ for glucose $(91.8 \pm 3.8 \mathrm{mM})$. GDH from $M b$. luteus was most active at $\mathrm{pH} 8.5\left(V_{\max }=43 \mathrm{U} / \mathrm{mg}\right.$ protein) and had lower $K_{\mathrm{m}}$ for glucose $(16 \pm 0.6 \mathrm{mM})$. The cells of two $\mathrm{Mtm}$. alcaliphilum double mutants with deletions either of the genes encoding GDH and glucokinase ( $\left.g d h^{-} / g l k^{-}\right)$or of the genes encoding gluconate kinase and glucokinase ( $\left.g n t k^{-} \mid g l k^{-}\right)$had the lower glycogen level and the higher contents of intracellular glucose and trehalose compared to the wild type strain. The gntk ${ }^{-} \mid g l k-$ knockout mutant additionally accumulated gluconic acid. These data, along with bioinformatics analysis, demonstrate that glycogen derived free glucose can enter the Entner-Doudoroff pathway or the pentose phosphate cycle in methanotrophs, bypassing glycolysis via the gluconate shunt.

Aerobic methanotrophs are a highly specialized group of bacteria that utilize methane as an energy and carbon source. Methanotrophs belong to the Alpha- or Gamma-classes of Proteobacteria, as well as to the phylum Verrucomicrobia. Only few representatives of alphaproteobacterial methanotrophs can utilize a limited range of polycarbon compounds and none of the methanotrophs can use sugars as growth substrates ${ }^{1-3}$. Nevertheless, bioinformatics and biochemical studies have shown that at least three pathways for cleavage of hexose phosphates are operative in gammaproteobacterial (Type I) methanotrophs: the modified pyrophosphate-dependent glycolysis, the Entner-Doudoroff pathway and the oxidative pentose phosphate cycle; the phosphoketolase glycolytic pathway is also encoded by the methanotrophs ${ }^{4}$. These routes start from hexose phosphates which are the first metabolites of the ribulose monophosphate (RuMP) pathway for $\mathrm{C} 1$ assimilation and lead to the formation of $\mathrm{C} 2, \mathrm{C} 3$ and $\mathrm{C} 4$ compounds, as well as to the redox cofactors $\mathrm{NAD}(\mathrm{P}) \mathrm{H}$ and ATP generation ${ }^{5,6}$. Moreover, the enzymes for glucose and fructose phosphorylation (ATP-glucokinase and ATP-fructokinase and, additionally, polyphosphate-dependent glucokinase in several species) have been characterized in Type I methanotrophs ${ }^{7-9}$. In spite of such a high versatility of carbohydrate metabolism, Type I methanotrophs demonstrate obligate dependence on $\mathrm{C} 1$ compounds and the biochemical basis of their inability to grow on polycarbon compounds remains unclear. Moreover, the genomic analysis also indicates that some Type I methanotrophs encode the putative glucose-1-dehydrogenase (GDH) and gluconate kinase (GntK), whose functionality still has to be elucidated (Fig. 1).

Glucose 1-dehydrogenases are the cofactor-dependent enzymes catalyzing oxidation of the first hydroxyl group of D-glucose to form D-glucono-1,5-lactone. The bacterial GDH (EC1.1.1.47) that catalyzes $\beta$-D-glucose oxidation, simultaneously converting $\mathrm{NAD}(\mathrm{P})^{+}$to $\mathrm{NAD}(\mathrm{P}) \mathrm{H}$, belongs to the extended superfamily of shortchain dehydrogenases/reductases (SDR) ${ }^{10}$. The enzymes of this family show the typical GXGXXG/A fingerprint motif found in most $\mathrm{NADP}^{+}$-binding proteins ${ }^{11,12}$. Then $\mathrm{D}$-glucono-1,5-lactone undergoes spontaneous hydrolysis in water (or by gluconolactonase) to gluconic acid, and the latter can be further phosphorylated to 6-phosphogluconate by gluconokinase (GntK) (EC 2.7.1.12). NADP ${ }^{+}$-GDHs have been described in grampositive heterotrophic bacteria and archaea $^{13}$. In archaea, however, GDH reaction product is further converted

${ }^{1}$ Federal Research Center "Pushchino Scientific Center for Biological Research of the Russian Academy of Sciences", G.K. Skryabin Institute of Biochemistry and Physiology of Microorganisms, Russian Academy of Sciences, Pushchino, Moscow Region, Russia 142290. ${ }^{2}$ Institute of Theoretical and Experimental Biophysics, Russian Academy of Sciences, Pushchino, Moscow Region, Russia $142290 .{ }^{\circledR}$ email: khmelenina@ibpm.pushchino.ru 


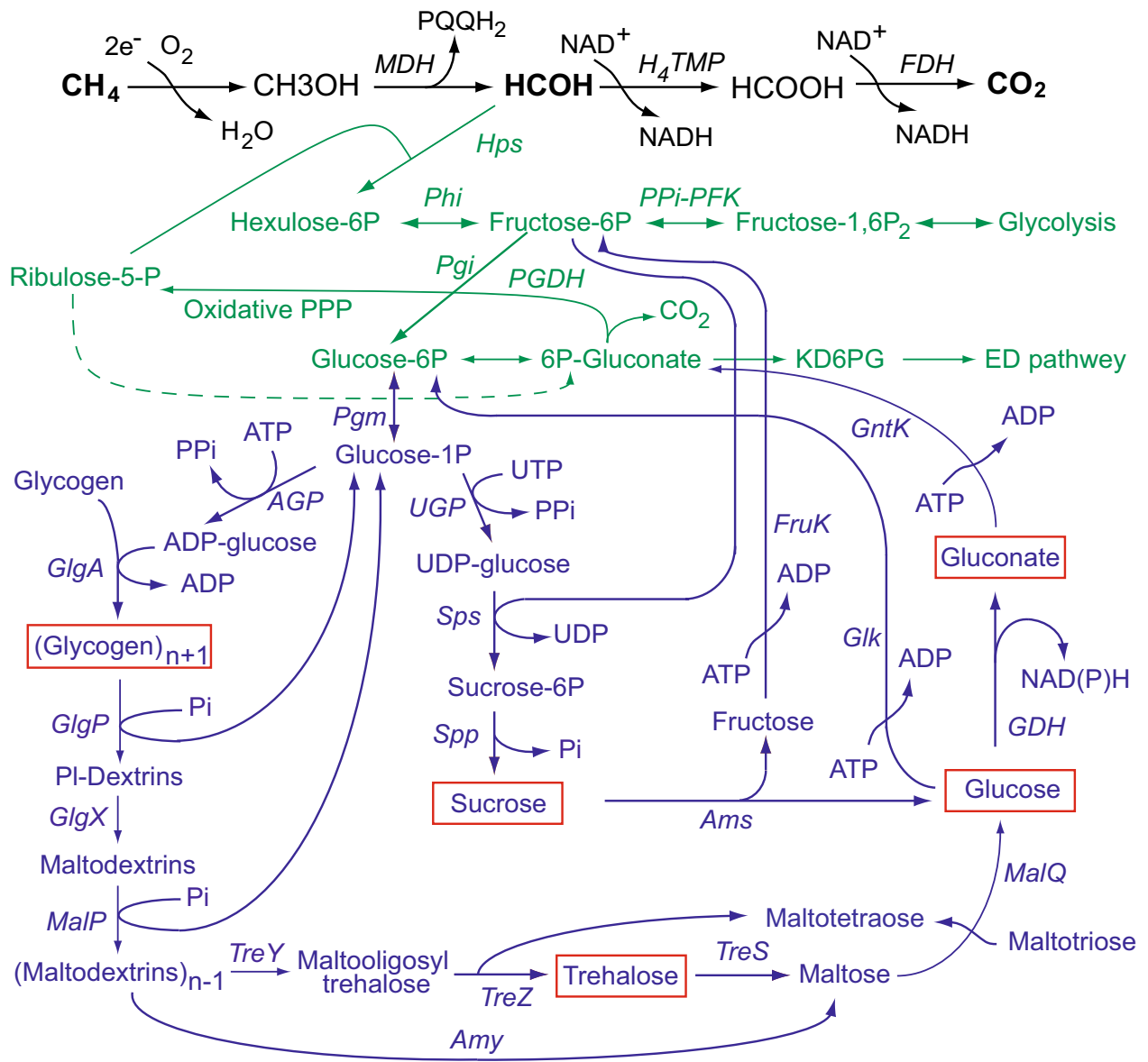

Figure 1. Schematic pathways for glycogen synthesis and degradation in Mtm. alcaliphilum 20Z. The methane oxidation reactions are black colored, the carbon assimilation pathways are green, the carbohydrate metabolism reactions are blue. $M M O$, methane monooxygenase; $M D H$, methanol dehydrogenase; $F D H$, formate dehydrogenase; HPS, hexulose-phosphate synthase; HPI, hexulosephosphate isomerase; PGI, phosphoglucose isomerase; $P G M$, phosphoglucose mutase; Glk, glucokinase; GntK, gluconate kinase; FruK, fructokinase; $U G P$, uridine glucopyrophosphorylase; $A G P$, adenosine glucopyrophosphorylase; $G l g A$, glycogen synthase; GlgP, glycogen phosphorylase; GlgX, debranching enzyme; TreY, maltooligosyl trehalose synthase; TreZ, trehalohydrolase; MalP, maltodextrin phosphorylases; TreS, trehalose synthase; MalQ, alpha-glucanotransferase; $A m s$, amylosucrase; Sps, sucrose-phosphate synthase; $S p p$, sucrose-phosphate phosphatase; GDH, glucose dehydrogenase; Gnl, lactonase. The genome analysis was carried out using NCBI and MicroScope databases (http://www.ncbi.nlm.nih.gov, https://mage.genoscope.cns.fr).

to 2-keto-3-deoxygluconate by gluconate dehydratase ${ }^{14}$. The Entner-Doudoroff pathway, which includes glucose dehydrogenase and gluconokinase, in addition to glycolysis and the oxidative pentose phosphate pathway, has been found in plants and cyanobacteria, and simultaneously anabolic (Calvin-Benson-Basham cycle) and catabolic processes (glycolytic pathways) have been demonstrated ${ }^{15,16}$.

This paper reports for the first time on the characteristics of $\mathrm{NAD}(\mathrm{P})^{+}$-dependent glucose dehydrogenase and gluconokinase in gram-negative bacteria unable to use carbohydrates as growth substrates. Characterization of the mutants with knockout of the enzymes leading to 6-phosphogluconate from free glucose, as well as bioinformatics analysis, have shown the in vivo functioning of the gluconate branch linking glycogen metabolism and the Entner-Doudoroff pathway in obligate methanotrophs.

\section{Results}

GDH-His ${ }_{6}$ expression, purification and structure. The sequences encoding the proteins with $39 \%$ identity to that of GDH characterized in Bacillus subtilis (BSU02830) were found in the Mtm. alcaliphilum and $M b$. luteus genomes. The full sequences of the respective ORFs (CCE23386 and WP_027157932) were expressed in E. coli Rosetta (DE3). The recombinant proteins, MtmGDH and MbGDH with 6 histidines at the N-termini, were purified by one-step affinity metal-chelating chromatography. SDS-PAGE of each enzyme revealed one band corresponding to a molecular mass of $\sim 30 \mathrm{kDa}$, which is in accordance with the theoretically calculated masses of $28.6 \mathrm{kDa}$ and $29.1 \mathrm{kDa}$ for GDH from Mtm. alcaliphilum or Mb. luteus, respectively. Gel filtration of the purified enzymes indicated a tetrameric structure of both methanotrophic GDHs (with Mr $112 \mathrm{kDa}$ for MtmGDH and $100 \mathrm{kDa}$ for MbGDH) (Fig. S1). 

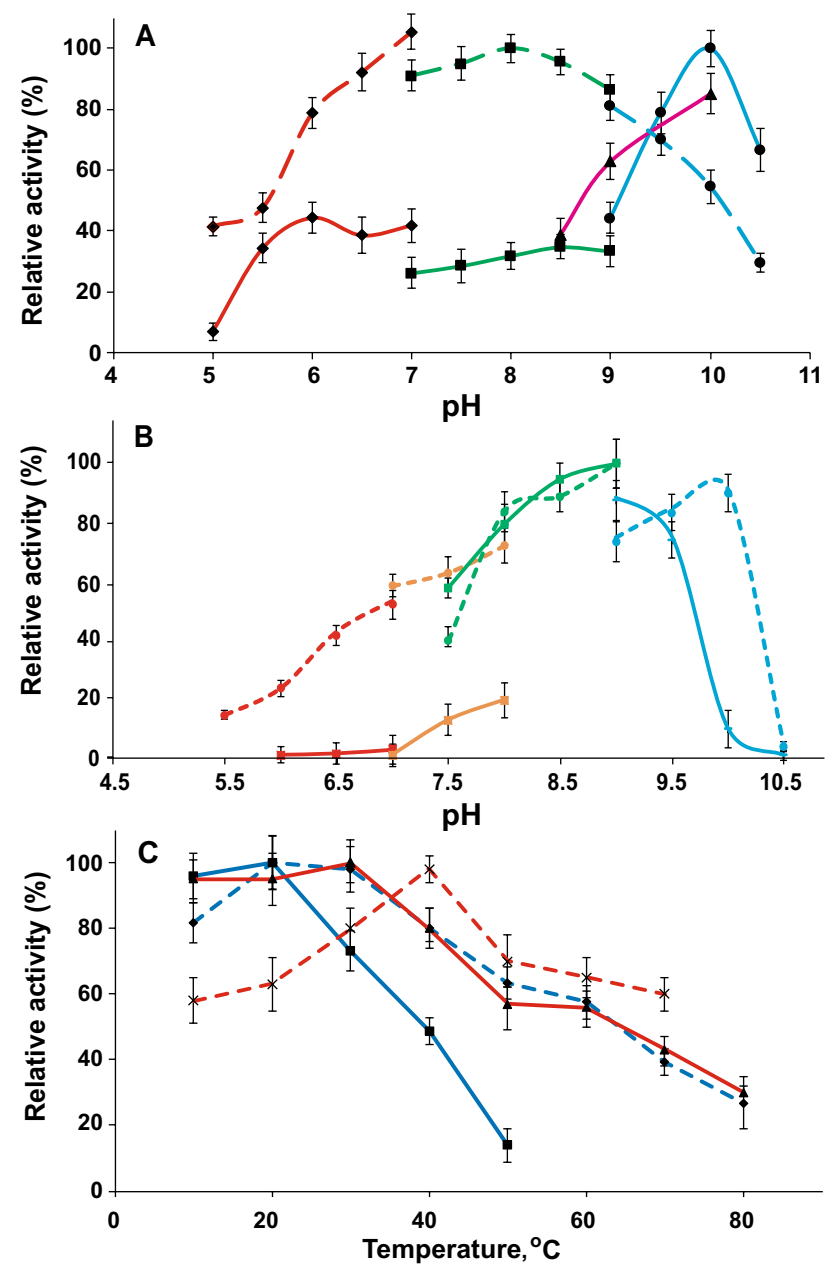

Figure 2. The effect of $\mathrm{pH}$ on the activity of GDHs (A) and GntKs (B) from Mtm. alcaliphilum (solid line) and $M b$. luteus (dashed line). The following buffers were used for activity measurement: MES-NaOH (red line), Tris-HCl (green line), K-P buffer (orange line), $\mathrm{CHES}-\mathrm{NaOH}$ (purple line), and Glycine-NaOH (blue line). $100 \%$ activity of GDH corresponds to $90 \mathrm{U} / \mathrm{mg}$ protein for $\mathrm{Mtm}$. alcaliphilum $\mathrm{GDH}$ and $28 \mathrm{U} / \mathrm{mg}$ protein for Mb. luteus GDH; $100 \%$ activity of GntK corresponds to 20 and $56 \mathrm{U} / \mathrm{mg}$ protein for Mtm. alcaliphilum and $\mathrm{Mb}$. luteus GntK, respectively. (C) The effect of temperature on the activity of GDHs (dark blue line) and GntK (red line) from Mtm. alcaliphilum (solid line) and Mb. luteus (dashed line).

Catalytic properties of GDHs. Both recombinant GDHs catalyzed the D-glucose-dependent reduction of $\mathrm{NAD}^{+}$or $\mathrm{NADP}^{+}$, but they were inactive with other sugars tested (L-glucose, fructose, mannose, galactose, sorbose and $\mathrm{N}$-acetyl-glucosamine). The enzyme from $\mathrm{Mtm}$. alcaliphilum was most active at $\mathrm{pH} 10.0$ (Fig. 2A) and $10-20^{\circ} \mathrm{C}$ (Fig. 2C). It lost $52 \%$ or $87 \%$ of activity after 1 -h exposure at $40{ }^{\circ} \mathrm{C}$ and $50{ }^{\circ} \mathrm{C}$, respectively. $50 \mathrm{mM}$ $\mathrm{NH}_{4} \mathrm{Cl}$ stimulated the enzyme activity 1.5 -fold (Supplementary Table S1). In the presence of $0.2 \mathrm{M} \mathrm{NaCl}$ or $2 \mathrm{M}$ $\mathrm{KCl}$, the enzyme activity decreased by $50 \%$ and $88 \%$, respectively, but chlorides of bivalent metals had no significant effect. The dependence of activity on the concentrations of substrates obeyed the Michaelis-Menten kinetics. The maximum reaction rate with $\mathrm{NAD}^{+}$was higher than with $\mathrm{NADP}^{+}$( 95 versus $39 \mathrm{U} / \mathrm{mg}$ protein) (Table 1). The apparent $K_{\mathrm{m}}$ values measured at $30^{\circ} \mathrm{C}$ and $\mathrm{pH} 10$ were as follows: $92 \pm 4 \mathrm{mM}$ for glucose, $0.36 \pm 0.02 \mathrm{mM}$ for $\mathrm{NAD}^{+}$, and $0.15 \pm 0.01 \mathrm{mM}$ for $\mathrm{NADP}^{+}$. For testing of influence of histidines on the kinetic parameters of MtmGDH, we carried out the cutting off $\mathrm{His}_{6}$-tags and found that the apparent $K_{\mathrm{m}}$ values for the substrates did not change compared to the $\mathrm{His}_{6}$-tagged enzyme (Table 1).

GDH from $M b$. luteus was most active at $\mathrm{pH} 8.0$ (Fig. $2 \mathrm{~A}$ ) and $20-30^{\circ} \mathrm{C}$ (Fig. 2C). The enzyme lost $37 \%$ and $61 \%$ of the activity after heating for $1 \mathrm{~h}$ at $50^{\circ} \mathrm{C}$ and $70^{\circ} \mathrm{C}$, respectively. The activity slightly increased in the presence of $50 \mathrm{mM} \mathrm{KCl}, \mathrm{NaCl}$ or $\mathrm{NH}_{4} \mathrm{Cl}$. However, in the presence of $0.25 \mathrm{M} \mathrm{NaCl}$ or $2 \mathrm{M} \mathrm{KCl}$, the residual activity was 84 and $39 \%$, respectively. The chlorides of $\mathrm{Ni}^{2+}, \mathrm{Cd}^{2+}, \mathrm{Zn}^{2+}$ and $\mathrm{Co}^{2+}$ completely inhibited $\mathrm{Mb}$. luteus GDH (Supplementary Table S1). The maximum of activity with $\mathrm{NADP}^{+}$was higher than with $\mathrm{NAD}^{+}(43 \mathrm{vs} 31 \mathrm{U} / \mathrm{mg}$ protein) (Table 1). MbGDH had a higher affinity for glucose compared to the Mtm. alcaliphilum enzyme $\left(K_{\mathrm{m}}\right.$ $16 \mathrm{mM}$ vs. $92 \mathrm{mM}$ ) but a lower affinity for $\mathrm{NADP}^{+}\left(K_{\mathrm{m}} 1.6 \mathrm{mM}\right.$ vs. $\left.0.01 \mathrm{mM}\right)$ (Table 1$)$. The calculated catalytic constants $k_{\text {cat }}$ and $k_{\text {cat }} / K_{\mathrm{m}}$ showed that both enzymes had low specificity for glucose and exhibited an order of magnitude higher specificity for $\mathrm{NAD}^{+}$than for $\mathrm{NADP}^{+}$(Table 1 ). The activities of both GDHs did not significantly 


\begin{tabular}{|c|c|c|c|}
\hline \multirow[b]{2}{*}{ Parameter } & \multicolumn{2}{|l|}{ Mtm. alcaliphilum } & \multirow[b]{2}{*}{ Mb. luteus } \\
\hline & \begin{tabular}{|l|} 
His $_{6}$-tag at the $\mathrm{N}$-terminus \\
\end{tabular} & Without $\mathrm{His}_{6}$-tag & \\
\hline M.m. (number of subunits), $\mathrm{kDa}$ & \multicolumn{2}{|l|}{$112(29 \times 4)$} & $100(29 \times 4)$ \\
\hline$V_{\max }, \mathrm{U} / \mathrm{mg}$ protein $\left(\mathrm{NAD}^{+}\right)$ & $95 \pm 3$ & ND & $31 \pm 2$ \\
\hline$V_{\max }, \mathrm{U} / \mathrm{mg}$ protein $\left(\mathrm{NADP}^{+}\right)$ & $39 \pm 2$ & ND & $43 \pm 6$ \\
\hline \multicolumn{4}{|l|}{$K_{\mathrm{m}}, \mathrm{mM}:$} \\
\hline Glucose & $92 \pm 4$ & $86 \pm 1$ & $16 \pm 1$ \\
\hline $\mathrm{NAD}^{+}$ & $0.36 \pm 0.02$ & $0.39 \pm 0.06$ & $0.12 \pm 0.02$ \\
\hline $\mathrm{NADP}^{+}$ & $0.14 \pm 0.01$ & $0.34 \pm 0.02$ & $1.6 \pm 0.3$ \\
\hline$k_{\text {cat NAD, }} 1 / \mathrm{min}$ & 10.6 & ND & 3 \\
\hline$k_{\text {cat NADP, }} 1 / \mathrm{min}$ & 0.35 & ND & 4 \\
\hline$k_{\text {cat }} / K_{\mathrm{m}}$ glucose, $1 /(\mathrm{mM} \times \min )$ & 0.1 & ND & 0.2 \\
\hline$k_{\text {cat }} / K_{\mathrm{m}}^{\mathrm{NAD}}, 1 /(\mathrm{mM} \times \mathrm{min})$ & 30 & ND & 26 \\
\hline$k_{\mathrm{cat}} / K_{\mathrm{m}} \mathrm{NADP}, 1 /(\mathrm{mM} \times \min )$ & 2.5 & ND & 2.7 \\
\hline Specificity $\left(k_{\text {cat }} / K_{\mathrm{m}}\right)^{\mathrm{NAD}} /\left(k_{\text {cat }} / K_{\mathrm{m}}\right)^{\mathrm{NADP}}$ & 12 & ND & 10 \\
\hline
\end{tabular}

Table 1. The kinetic properties of GDHs from methanotrophs. ND not determined.

\begin{tabular}{|l|l|l|}
\hline Parameter & Mtm. alcaliphilum & Mb. luteus \\
\hline M.m. (number of subunits), $\mathrm{kDa}$ & $20(1)$ & $20(1)$ \\
\hline$V_{\max }, \mathrm{U} / \mathrm{mg}$ protein & $25.8 \pm 0.4$ & $56.1 \pm 0.9$ \\
\hline $\boldsymbol{K}_{\mathrm{m}}$ or $\mathbf{S}_{0.5}{ }^{*}, \mathbf{m M :}$ & \multicolumn{2}{|l|}{} \\
\hline Gluconate & $0.6 \pm 0.04$ & $0.24 \pm 0.01$ \\
\hline ATP & $1.3 \pm 0.2^{*}(\mathrm{n}=1.6)$ & $0.042 \pm 0.002^{*}(\mathrm{n}=2.3)$ \\
\hline$k_{\text {cat }}{ }^{\text {lluconate }}, 1 / \mathrm{min}$ & 0.26 & 0.77 \\
\hline$k_{\text {cat }}{ }^{\text {TTP }}, 1 / \mathrm{min}$ & 0.52 & 1.1 \\
\hline$k_{\text {cat }} / K_{\mathrm{m}}$ gluconate,, $1 /(\mathrm{mM} \times \min )$ & 0.4 & 3.2 \\
\hline$k_{\text {cat }} / K_{\mathrm{m}}{ }^{\text {ATP }}, 1 /(\mathrm{mM} \times \min )$ & 0.4 & 26 \\
\hline
\end{tabular}

Table 2. The kinetic properties of GntKs from methanotrophs.

vary in the presence of various organic metabolites (Supplementary Table S2). The activity of MtmGDH slightly increased (by 40\%) in the presence of $1 \mathrm{mM}$ isocitrate, and the activity of $\mathrm{Mb}$. luteus GDH decreased by $40 \%$ in the presence of $10 \mathrm{mM}$ glucose-6-phosphate.

Expression, purification and structure of $\mathrm{GntK}_{\mathrm{H}} \mathrm{His}_{6}$ from methanotrophs. The genes encoding the gluconate kinase from Mtm. alcaliphilum (CE23379) and Mb. luteus (WP_051299846) were heterologously expressed in E. coli Rosetta (DE3). The recombinant proteins MtmGntK and MbGntK with 6 histidines at the C-terminus were purified by affinity Ni-NTA chromatography. SDS-PAGE of each enzyme showed one band corresponding to a molecular mass of $\sim 20 \mathrm{kDa}$, which is consistent with the theoretically calculated masses. Gel filtration of the purified enzymes indicated a monomeric structure of both GntKs (Fig. S1).

Catalytic properties of GntKs from methanotrophs. The recombinant MtmGntK demonstrated activity $26 \mathrm{U} / \mathrm{mg}$ protein. The enzyme was active in the $\mathrm{pH}$ range from $\mathrm{pH} 7.5$ to $\mathrm{pH} 9.5$ with the optimum at $\mathrm{pH} 9.0$ (Fig. 2B) and in the temperature range from 10 to $30^{\circ} \mathrm{C}$ (Fig. 2C). It was quite stable, withstanding 2-h heating at $30-50{ }^{\circ} \mathrm{C}$ without a decrease in activity. Nonetheless, its activity was fully lost after 5-min exposure at $70{ }^{\circ} \mathrm{C}$. No allosteric regulators were found for MtmGntk; however, various metals significantly reduced the activity (Supplementary Tables S1, S3). Thus, $\mathrm{CuCl}_{2}, \mathrm{CdCl}_{2}, \mathrm{NiCl}_{2}, \mathrm{ZnCl}_{2}$ and $\mathrm{BaCl}_{2}$ at a concentration of $1 \mathrm{mM}$ almost fully inhibited the activity, while $\mathrm{CaCl}_{2}$ and $\mathrm{CoCl}_{2}$ decreased the activity by 60 and $70 \%$, respectively. $50 \mathrm{mM} \mathrm{NH}_{4} \mathrm{Cl}$ and $\mathrm{KCl}$ reduced the activity by $30 \% .50 \mathrm{mM} \mathrm{NaCl}$ had no influence on the enzyme activity whereas in the presence of $0.5 \mathrm{M} \mathrm{NaCl}$ the activity of MtmGntK decreased by $80 \%$. The dependence of the MtmGntK activity on gluconate concentration obeyed the Michaelis-Menten kinetics: the apparent $K_{\mathrm{m}}$ value was $0.60 \pm 0.03 \mathrm{mM}$ (Table 2). In response to the changes in ATP concentration, the enzyme behavior did not obey the Michaelis-Menten kinetics: the $S_{0.5}$ value, $1.3 \pm 0.2 \mathrm{mM}$; the Hill coefficient, $n=1.6$.

The maximal activity of MbGntK under optimal conditions ( $\mathrm{pH} \mathrm{9.0,40}{ }^{\circ} \mathrm{C}$ ) was $56 \mathrm{U} / \mathrm{mg}$ protein (Fig. 2). Unlike MtmGntK, the enzyme from $\mathrm{Mb}$. luteus fully lost the activity after 5 -min exposure at $50{ }^{\circ} \mathrm{C}$, while the activity did not change after 2 -h exposure at $30^{\circ} \mathrm{C}$. No allosteric regulator of the enzyme was found. $\mathrm{CuCl}_{2}$ almost completely suppressed the $\mathrm{MbGntK}$ activity, while $\mathrm{CdCl}_{2}$ and $\mathrm{ZnCl}_{2}$ reduced its activity by 80 and $70 \%$, respectively (Supplementary Table S1). The activity slightly increased in the presence of monovalent cations $\mathrm{Na}^{+}$and 


\begin{tabular}{|l|l|l|l|l|l|l|l|}
\hline $\begin{array}{l}\text { Metabolite } \\
\text { Growth substrate }\end{array}$ & Sucrose & Glycogen & Glucose & Gluconate & Trehalose & Glucose-1P & Glucose-6P \\
\hline WT & $17.3 \pm 0.9$ & $138 \pm 8$ & $0.14 \pm 0.04$ & ND & $0.04 \pm 0.01$ & $0.12 \pm 0.02$ & $0.09 \pm 0.01$ \\
\hline Methane & $12.2 \pm 0.3$ & $322 \pm 9$ & $1.27 \pm 0.03$ & ND & $0.06 \pm 0.01$ & $0.10 \pm 0.06$ & $0.18 \pm 0.03$ \\
\hline Methanol & $4.9 \pm 1.2$ & $0.20 \pm 0.04$ & $7.3 \pm 1.1$ & ND & $0.56 \pm 0.16$ & $0.12 \pm 0.01$ & $0.13 \pm 0.08$ \\
\hline gdh/glk $/ 8$ & $32.2 \pm 1.4$ & ND & $0.83 \pm 0.11$ & $0.26 \pm 0.11$ & $0.41 \pm 0.03$ \\
\hline Methane & $0.82 \pm 0.08$ & $4.9 \pm 0.5$ & & & & \\
\hline Methanol & $8.7 \pm 2.0$ & $1.24 \pm 0.06$ & $0.41 \pm 0.04$ & $0.83 \pm 0.14$ & $0.16 \pm 0.1$ & $0.14 \pm 0.04$ & $0.15 \pm 0.01$ \\
\hline gntk/glk & $7.6 \pm 1.2$ & $56 \pm 5$ & $5.3 \pm 1.1$ & $1.30 \pm 0.23$ & $1.84 \pm 0.18$ & $0.24 \pm 0.11$ & $0.2 \pm 0.02$ \\
\hline Methane
\end{tabular}

Table 3. Accumulation of carbohydrates (mg per g of DCW) in the wild type (WT) cells of Mtm. alcaliphilum and mutant strains deficient in glucose dehydrogenase/glucokinase $\left(g d h^{-} / g l k^{-}\right)$and gluconate kinase/ glucokinase $\left(g n t k^{-} / g l k^{-}\right)$. ND, not detected. The samples for analyses were drawn at late exponential phase of the culture growth.

$\mathrm{NH}_{4}^{+}(50 \mathrm{mM})$; however, in the presence of 0.5 or $1 \mathrm{M} \mathrm{NaCl}$, the activity decreased by 70 or $10 \%$, respectively. The apparent $K_{\mathrm{m}}$ value for gluconate was $0.23 \pm 0.01 \mathrm{mM}$. Similarly to the enzyme from Mtm. alcaliphilum, the dependence of MbGntK activity on ATP concentration did not obey the Michaelis-Menten kinetics; $S_{0.5}$ was $0.042 \pm 0.002 \mathrm{mM}$, the Hill coefficient $n=2.3$.

The activities of GDH and Glk in cell-free extracts of methanotrophs. The activity of GDH in cellfree extracts of $\mathrm{Mtm}$. alcaliphilum was found to be $20 \mathrm{mU} / \mathrm{mg}$ protein in the presence of $200 \mathrm{mM}$ glucose in the reaction mixture, but the reaction quickly stopped if $20 \mathrm{mM}$ glucose concentration was used to measure the activity. It corresponded with the extraordinary high apparent $K_{\mathrm{m}}$ value $(92 \mathrm{mM})$ found for the purified enzyme. This implies the in vivo expression of glucose dehydrogenase in Mtm. alcaliphilum. The specific activity of GDH in the cell-free extracts of $M b$. luteus in the presence of $200 \mathrm{mM}$ glucose was $28 \mathrm{mU} / \mathrm{mg}$ protein; at $20 \mathrm{mM}$ glucose, it was $\sim 14 \mathrm{mU} / \mathrm{mg}$ protein.

The specific activity of glucokinase (Glk) in cell-free extracts of $M t m$. alcaliphilum was $\sim 30 \mathrm{mU} / \mathrm{mg}$ protein. In response to the increase of glucose concentration from 5 to $200 \mathrm{mM}$ in the reaction mixture, the enzyme activity increased to $60 \pm 5 \mathrm{mU} / \mathrm{mg}$ protein. This increase can be explained by appearance of the low affinity GDH.

The analysis of activities of the putative promoter regions of the gntk and amy genes. We were unsuccessful to find activity of gluconate kinase in the cell-free extracts from both methanotrophs. Therefore, using cat as a reporter gene (encoding chloramphenicol acetyltransferase), we analyzed the activities of the putative promoter region of the gntk gene in Mtm. alcaliphilum. In cell-free extracts of Mtm. alcaliphilum pMHA:Pgntk-cat grown under methane or in the presence of methanol, the activities of chloramphenicol acetyltransferase were $2.6 \pm 0.8$ and $5.1 \pm 0.3 \mathrm{mU} / \mathrm{mg}$, respectively.

In Mtm. alcaliphilum, $10 \mathrm{bp}$ upstream the gntk gene the amy gene encoding alpha amylase is located (Fig. S2). The activity of the amy promoter was also analyzed. When Mtm. alcaliphilum pMHA:Pamy-cat was grown on methanol or under methane, the activities of chloramphenicol acetyltransferase were found $(9.7 \pm 0.5$ or $6.0 \pm 0.3 \mathrm{mU} / \mathrm{mg}$ respectively). Consequently, one may expect that the gntk and amy genes are functional.

Phenotypic characterization of insertional mutants. To prove the in vivo glucose metabolism through the GDH/GntK reactions in Mtm. alcaliphilum, the strain with insertion in the $g d h$ gene was obtained but changes in growth characteristics in the mutant strain were not identified. This can be due to the operation of glucokinase highly specific to glucose $\left(K_{\mathrm{m}} 0.32 \mathrm{mM}\right)^{8}$. In the double mutated strain $g \mathrm{kt}^{-} / \mathrm{glk}^{-}$, the GDH activity was $22 \pm 5 \mathrm{mU} / \mathrm{mg}$ protein but Glk activity was not detected. The $g d h^{-} / g l k^{-}$strain lacked both GDH and Glk activities.

In the presence of methane or methanol, the double mutation strains grew 1.5 times slower compared to the wild type (WT) strain 20Z (Fig. 3S). The same effect was observed in a single $g l k^{-}$mutant ${ }^{8}$. In contrast to the $g l k^{-}$ strain, where the content of intracellular glucose did not actually differ from the WT strain ${ }^{8}$, the intracellular pools of glucose in the $g d h^{-} / g l k^{-}$strain grown on methane or methanol increased 50- and 32-fold, respectively (Table 3). At the same time, the glucose content in cells of the $g n t k^{-} / g l k^{-}$strain increased only 3-4 times regardless of the growth substrate. Only a slight increase in glucose in the $g n t k^{-} / g l k^{-}$mutant indicated the functioning of GDH, which converts excess glucose into gluconate. Another evidence of the functionality of GDH and GntK enzymes is accumulation of gluconic acid in the $g n t k^{-} / g l k^{-}$strain (Table 3). In cells of these mutants grown in either methane or methanol, glycogen accumulation dramatically decreased (Table 3 ). It should be noted that glycogen concentration in the methane grown $g d h^{-} / g l k^{-}$strain dropped 690 times compared to the WT strain, whereas a minor glycogen decrease was observed in the methanol-grown $g n t k^{-} / g l k^{-}$strain ( $\sim 6$ times). The gntk ${ }^{-} /$ $g l k^{-}$strain growing on methanol accumulated the highest level of intracellular trehalose, but least of all when growing under methane (Table 3). In cells of the $g n t k^{-} / g l k^{-}$and $g d h^{-} / g l k^{-}$strains growing on methanol a mixture 
96. Methylobacter marinus (WP 020161354)

100l Methylobacter whittenburyi (WP 036294807)

99 Methylobacter sp. BBA5.1 (WP 036251157)

- Methylobacter luteus (WP 027157932)

- Nitrosomonas communis (TYP78559)

98 - Nitrosomonas halophila (SDX91922)

- Nitrosomonas nitrosa (HBZ30297)

93 Methylotuvimicrobium alcaliphilum (CCE23386)

100 Methylotuvimicrobium buryatense (WP 017838996)

Bradyrhizobium canariense (SDT55222)

Streptomyces globisporus (WP 030589908)

100-Methylocaldum marinum (WP 119630246)

Methylocaldum sp. 0917 (WP 133718328)

Thermoflavifilum aggregans (PJJ74821)

Nitrosococcus wardiae (WP 134357479)

64

${ }^{87}$ Fischerella sp. NIES-4106 (WP 096676622)

L Nostoc punctiforme (WP 012408472)

100 - Anabaenopsis circularis (BAY16517)

- Calothrix brevissima (WP 096646716)

L Nostoc piscinale (WP 062291054)

Methylosarcina fibrata (WP 020562753)

Thiobacillus sp. (TXH73979)

50

71 - Bacillus subtilis (ABR21558)

Bacillus megaterium (D10626)
$100 \quad$ Lysinibacillus sphaericus (ACR78513)

54 Bacillus sp.ZJ (AID68564)

97. Bacillus anthracis (AFH86129)

7d. Bacillus thuringiensis (YP 038762)

Corynebacterium glutamicum (BAU96964) Methylomonas sp. LW13 (WP 084153366)

00 Methylomonas sp. 11b (WP 026603604)

100 Methylomonas denitrificans (AMK77075) 100 Methylomonas methanica (2745445983)

54 Methylomicrobium album (METBGV2 21662)

Methylocucumis oryzae (WP 045778981)

- Methyloglobulus morosus (AYLOv1 510033)

91 Methylobacillus flagellatus (WP 137718238)

91 - Methylovilum miyakonense (WP 019867146)

95 Methylovilum psychrotolerans (WP 088617963) Methylomagnum ishizawai (WP 085216544)

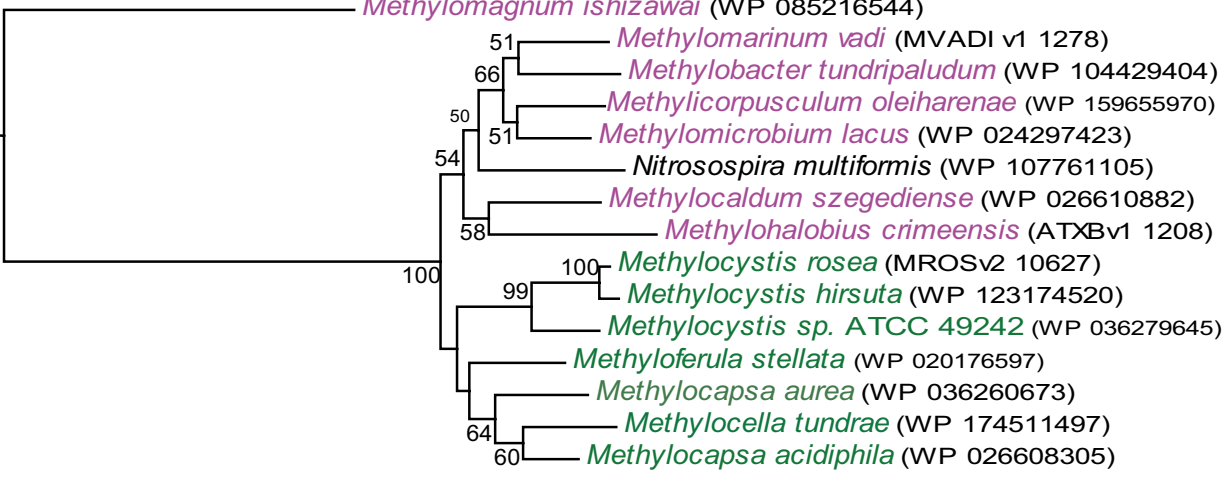

$\longmapsto 0.2$

Figure 3. The phylogenetic tree built of the amino acid sequences of various putative and characterized bacterial NAD $(\mathrm{P})^{+}$-dependent glucose dehydrogenases. The characterized enzymes are in bold: Bacillus thuringiensis ${ }^{17}$, Bacillus sp. $\mathrm{ZJ}^{18}$, Bacillus megaterium ${ }^{19}$, Bacillus subtilis ${ }^{20}$ and Lysinibacillus sphaericus ${ }^{21}$. The amino acid accession numbers in the Gene Bank are in brackets. Gammaproteobacterial methanotrophs are purple colored, alphaproteobacterial methanotrophs are green colored. The scale bar corresponds to the number of substitutions per site. The sequences from NCBI, IMG/MER and MicroScope databases (http://www.ncbi. nlm.nih.gov, https://mage.genoscope.cns.fr/, https://img.jgi.doe.gov/) were obtained by BLAST searches. The alignments of amino acid sequences and the phylogenetic analysis were performed using MEGA 6 and the Neighbor-Joining model ${ }^{22}$. 
of malto-derivatives of carbohydrates were detected, but it was very difficult to identify these compounds (the individual components of the mixture) by the $\mathrm{H}^{1}$-NMR method.

The sequence and distribution of GDH in methanotrophs. As can be judged from protein sequences, GDHs from Mtm. alcaliphilum and $\mathrm{Mb}$. luteus belong to the superfamily of short-chain dehydrogenases/reductases (SDR). These enzymes show the typical GXGXXG fingerprint motif found in NADP ${ }^{+}$-binding proteins ${ }^{11,12}$ (Fig. 4S). There are some differences in the composition of amino acids forming the active center in GDH from Bacillus megaterium and those from Mtm. alcaliphilum and Mb. luteus (marked ${ }^{*}$ in Fig. $4 \mathrm{~S}$ ). The amino acids at the C-terminus of B. megaterium GDH (Q257, A258, R260 and G261) directly interact with glucose and thus determine the kinetic properties of the enzyme. The C-termini at GDHs from Mtm. alcaliphilum and Mb. luteus are significantly different from the C-terminus of the B. megaterium enzyme, which may be reflected in the kinetic properties of methanotrophic enzymes (Fig. 4S). The only difference in amino acids forming hydrogen bonds with the hydroxyl groups of glucose between the Mtm. alcaliphilum and Mb. luteus GDHs is the replacement of aspartate (D219) by glutamate (E219). The GDHs from other methanotrophs have more differences in amino acids presumably forming the active center and interacting with glucose (Fig. 4S).

Analysis of the genome databases available showed that only a number of methanotrophs have GDH homologues (Fig. 3, Supplementary Table S4). GDH homologs are present in some other Type I methanotrophs: Methylosarcina fibrata (60\% identity of translated amino acids to MtmGDH) and some representatives of the genera Methylocaldum (62\% identity) and Methylomonas (29\% identity) (Fig. 3). However, the genomes of Methylomonas and Methylosarcina have no gene for gluconate kinase. At the same time, gluconate kinases from Mtm. alcaliphilum, Methylocaldum szegediense and Methylocella silvestris have only 32-37\% identity with each other.

A number of other methanotrophs have putative GDHs, which have very low similarity (14-27\% identity) to Mtm. alcaliphilum and Bacillus megaterium enzymes, but belong to the SDR family (Fig. 3).

\section{Discussion}

In this study we have characterized for the first time glucose dehydrogenase and gluconate kinase, the starting enzymes for glucose metabolism, in aerobic methanotrophs, bacteria which unable to use sugars as growth substrates. The GDHs from Mtm. alcaliphilum and $M b$. luteus are strongly specific for D-glucose and use $\mathrm{NAD}^{+}$ as the preferred cofactor. To date, microbial NAD $(\mathrm{P})^{+}-\mathrm{GDHs}$ have been characterized in gram-positive bacteria, cyanobacteria, archaea, fungi and yeasts, as well as in plants, whereas GDHs investigated in gram-negative bacteria were PQQ-dependent ${ }^{23}$. GDHs from Bacilli can oxidize a broad range of substrates ${ }^{24}$. The NAD $(\mathrm{P})^{+}-\mathrm{GDH}$ from $B$. thuringiensis oxidizes glucose $\left(K_{\mathrm{m}} 14 \mathrm{mM}\right)$ and 2-deoxy-D-glucose $\left(K_{\mathrm{m}} 12.2 \mathrm{mM}\right)^{17}$, and the enzyme from Lysinibacillus sphaericus also oxidizes disaccharides such as maltose, lactose, and sucrose ${ }^{21}$. GDHs from the archaea Thermoproteus tenaxis and Sulfolobus solfataricus have $K_{\mathrm{m}} 0.3-0.4 \mathrm{mM}$ for glucose, $K_{\mathrm{m}}$ values for the enzymes from bacteria utilizing the sugar as growth substrate are in a wide range $(0.5-42 \mathrm{mM})^{23,25}$ and $K_{\mathrm{m}}$ of the enzyme from $M b$. luteus is within the same range. Curiously, GDH from Mtm. alcaliphilum remains the absolute record holder for the highest $K_{\mathrm{m}}(92 \mathrm{mM})$. Similarly to the GDHs from Bacillus sp. ZJ and L. sphaericus $^{18,21}$, methanotrophic GDHs are tetramers.

Previously, a single $g l k^{-}$mutant exhibiting a drastic decrease in glycogen level (50 times compared to the WT strain) has been characterized while its intracellular glucose level remained almost unaltered ${ }^{8}$. In this work, the $g d h^{-} / g l k^{-}$mutant lacking genes for both enzymes responsible for activation of free glucose demonstrated considerable increase in intracellular glucose content (Table 3). This indicated that, despite the high $K_{\mathrm{m}}$, GDH in Mtm. alcaliphilum is involved in maintaining the intracellular pool of glucose. Only a slight increase of glucose content in the $g n t k^{-} / g l k^{-}$strain additionally confirmed participation of GDH in utilization of the sugar. The occurrence of gluconate in the $g n t k^{-} / g l k^{-}$strain where the gene for gluconate kinase is turned off and GDH working, proves the in vivo participation of both enzymes in free glucose removal.

In cells of the $g l k^{-}, g d h^{-} / g l k^{-}$and $g n t k^{-} / g l k^{-}$strains, trehalose level was drastically increased as compared to the WT cells. The genomic analysis allows us to propose that only glycogen can be a source of trehalose. Thus, the genome of Mtm. alcaliphilum harbors the tre $Y$ and treZ genes encoding putative maltooligosyltrehalose synthase (CCE23905) and trehalohydrolase (CCE23904) which convert the terminal unit of the linear maltodextrin (glycogen or starch) into trehalose via maltooligosyltrehalose (Fig. 3). It also has the gene for putative maltose alpha-D-glucosyltransferase (trehalose synthase, TreS, CCE22655) which catalyzes the reversible conversion of maltose into trehalose as described for the first time in mycobacteria ${ }^{26}$. At the same time, Mtm. alcaliphilum lacks the ots $A$-ots $B$ genes encoding trehalose 6-phosphate synthase and trehalose 6-phosphate phosphatase responsible for trehalose synthesis at many (micro)organisms. The methanotroph has gene encoding 4 -alphaglucanotransferase (MalQ, CCE25166) which recognizes maltose and longer maltodextrins and preferentially removes glucose from the reducing ends of maltose and from small maltodextrins and transfers the remaining enzyme-bound dextrinyl residue to the non-reducing ends of other maltodextrins, thus forming longer maltodextrin chains ${ }^{27}$. Two Glg enzymes are essential for endogenous maltotriose formation in Mtm. alcaliphilum: glycogen phosphorylase GlgP (CCE22814; CCE22130; CCE25654) which shortens the branch chains of glycogen to the lengths of maltotetraosyl and maltotriosyl units, and GlgX (CCE25166), which releases the branch chains. Some GlgPs can act as maltodextrin phosphorylases MalP ${ }^{28}$ (Fig. 1). Therefore, glycogen serves as the main source of free glucose for GDH and Glk reactions. Since glucose and trehalose were found in wild type cells (Table 3), the process of glycogen degradation in Mtm. alcaliphilum most likely goes along with glycogen synthesis. The concerted action of glycogen synthesizing and degrading enzymes has been recently revealed in Corynebacterium glutamicum and E. coli ${ }^{29}$. The simultaneously occurring glycolysis and the oxidative pentose phosphate pathway in addition to the Entner-Doudoroff pathway shunt including glucose dehydrogenase and gluconate kinase has been proven for plants and cyanobacteria ${ }^{15,16,30}$. 
In Mtm. alcaliphilum 20Z, glucose derived from glycogen degradation is utilized mainly by glucokinase due to its higher specificity to the sugar than GDH. The glucose 6-phosphate formed in Glk reaction is further converted by phosphoglucose isomerase into fructose 6-phosphate, which enters glycolysis after phosphorylation by PPidependent phosphofructokinase and/or the Entner-Doudoroff pathway via glucose 6-phosphate dehydrogenase. In the case of glycogen decomposition and/or inhibition of glucokinase activity by $\operatorname{ADP}^{8}\left(K_{\mathrm{i}} 2.34 \mathrm{mM}\right)$, GDH can be involved in the glucose utilization. It should be noted that 6-phosphogluconate is a substrate for 6-phosphogluconate dehydrogenase reaction which produces ribulose 5-phosphate, an acceptor of formaldehyde in the key reaction of carbon assimilation catalyzed by hexulosephosphate synthase (Fig. 1). Therefore, metabolism of glucose via the gluconate shunt can be an anaplerotic mechanism that replenishes the RuMP cycle by tapping cellular carbohydrate reservoirs under fluctuations in content of carbon substrate in the environment.

The ability of these bacteria to obtain the key central metabolites from glycogen could allow them to survive the lack of the growth substrate in the environment at the expense of their own internal resources. Previous studies have shown that thermotolerant methanotroph Methylococcus strain NCIB 11083 can metabolize glycogen under aerobic starvation conditions, and this process could generate sufficient energy for protein synthesis in the absence of methane ${ }^{31}$. Recently we have shown that inactivation of the genes encoding the key enzymes of sucrose and glycogen synthesis reduced growth rate of $\mathrm{Mtm}$. alcaliphilum mutant on methane or methanol and increased the protein content in cells of the methanotroph ${ }^{32}$.

The reasons for the inhibition of growth of the strains lacking the genes for metabolism of free glucose are still unclear. Apparently, the accumulation of glucose in the cytoplasm and dramatic drop in glycogen level in the mutants indicate a permanent process of decomposition of glycogen, and inhibition of the polymer synthesis (Fig. S5). The molecular mechanisms underlying the regulation of the synthesis and degradation of the storage polymer in bacteria remain to be elucidated. A direct non-enzymatic effect of glucose on bacterial proteins/ enzymes and the triggering of stress responses are not excluded ${ }^{33}$.

The genomic analyses showed that all Type I methanotrophs possess genes encoding glycogen synthase (Supplementary Table 4S). They also harbor up to two genes for glucokinases with a single exception Methylocaldum marinum S8 lacking Glk encoding gene. None of them encode PTS system for glucose transport. The GDH homologues present in Type I methanotrophs (usually along with GntK ones) with exceptions of Methylococcus capsulatus (Bath and Texas), Methylomonas methanica MC09, Methylomonas sp. MK1 and Methylotuvimicrobium kenyense AMO1 lacking both gluconate shunt enzymes. Several species, for example Methylosarcina fibrata AML-C10 and Methylomicrobium album BG8 encode gluconate dehydrogenase (GntD) instead of the GntK thuds implying another variant of non-phosphorylated gluconate shunt (Supplementary Table 4S).

Among Type II methanotrophs, synthesizing hexosephosphates mainly through gluconeogenesis, almost all representatives have GlgA encoding genes (Supplementary Table 4S). The exceptions are all Methylosinus strains and Methylocystis sp. LW5 lacking glgA genes. About half of the genomes of this group methanotrophs sequenced today also code GDH and few species also have Glk encoding genes. All Type II methanotrophs possess genes for PTS system for sugar transport. Thus, genomic analysis demonstrates high versatility of carbohydrate metabolism in methanotrophs, the bacteria unable to grow on any sugars. The redundancy of the pathways of sugar metabolism in obligate methanotrophs determines their ability to survive under the conditions of $\mathrm{CH}_{4}$ deficiency, but the question about the causes of their inability to use glucose as a carbon and energy source for growth is still open.

\section{Materials and Methods}

Bacteria and growth conditions. Mb. luteus (IMV-B-3098) and Mtm. alcaliphilum 20Z (VKM $\mathrm{B}-2133^{\mathrm{T}}=\mathrm{NCIMB} 14124^{\mathrm{T}}$ ) were grown at $30^{\circ} \mathrm{C}$ on a nitrate salt medium. For the growth of Mtm. alcaliphilum 20Z, the medium additionally contained $0.1 \mathrm{M} \mathrm{NaHCO}_{3}$ and $0.3 \mathrm{M} \mathrm{NaCl}^{34}$. Methane (50\% in the gas phase) or methanol $(0.5 \%, \mathrm{v} / \mathrm{v})$ was used as a carbon source. Escherichia coli Rosetta (DE3) obtained from Stratagene (La Jolla) was grown at $37^{\circ} \mathrm{C}$ on a Luria-Bertani (LB) agar or in broth. Kanamycin $(50 \mu \mathrm{g} / \mathrm{mL})$ and/or chloramphenicol $(25 \mu \mathrm{g} / \mathrm{mL})$ was added to the growth medium as necessary.

Cloning, preparation and purification of the recombinant enzymes. To amplify the gene encoding ubiquitin with 6 histidines at the $\mathrm{N}$-terminus from the pHUE plasmid (Supplementary Table S5), the Ub-F/ Ub-R primers (Supplementary Table S6) and vector pET28 for cloning were used. The $g d h$ gene was amplified by PCR from the DNAs of Mtm. alcaliphilum or Mb. luteus using the primers presented in the Supplementary Table S4. The purified PCR product corresponding to the Mtmgdh gene was ligated into the pET28 or pET28Ub-shHis vectors at the NdeI/HindIII or SacII/HindIII restriction sites, respectively. The PCR product carrying the Mbgdh gene was ligated into pET28Ub-shHis at the SacII/HindIII restriction sites. The resulting vectors pET28:gdhMtm, pET28Ub-shHis:gdhMtm, or pET28Ub-shHis:gdhMb were transferred into E. coli Rosetta (DE3), enzyme synthesis was induced by $0.5 \mathrm{mM}$ isopropyl- $\beta$-D-thiogalactopyranoside, and cells were incubated for $15 \mathrm{~h}$ at $18{ }^{\circ} \mathrm{C}$. Recombinant enzymes with $\mathrm{His}_{6}$ at the $\mathrm{N}$-termini were purified as described ${ }^{35}$. To remove His-tags, the enzymes were incubated for $18 \mathrm{~h}$ with Usp2-His ${ }_{6}$ protease $(50 \mu \mathrm{g}$ of protease per $1 \mathrm{mg}$ of protein) at $+4{ }^{\circ} \mathrm{C}$. The efficiency and completeness of hydrolysis were checked by SDS-PAAG electrophoresis. The final purification of GDH preparations from the cut-off His-tag and Usp2-His6 were not carried out, since $\mathrm{GDH}$ activity was lost during dialysis.

The vector pET30 (Novagen) was used to amplify the gntk genes from methanotrophic DNAs by the respective primers (Supplementary Table S6). The resulting vector pET30:gntkMtm or pET30:gntkMb was transferred into E. coli Rosetta (DE3). The purification of the recombinant GntKs was carried out as described above. Purified recombinant enzymes were stored in $40 \%$ glycerol at $-20^{\circ} \mathrm{C}$. 
Determination of molecular weight of recombinant enzymes. Gel filtration was performed on the XK 16/100 Superdex 200 column (GE Healthcare) balanced with $0.02 \mathrm{M}$ Tris- $\mathrm{HCl}(\mathrm{pH}$ 7.0) containing $0.5 \mathrm{M} \mathrm{NaCl}$. The following protein markers (Sigma-Aldrich) were used to build the calibration curve: carbonic anhydrase $(29 \mathrm{kDa})$, albumin $(66 \mathrm{kDa})$, alcohol dehydrogenase $(150 \mathrm{kDa}), \beta$-amylase $(200 \mathrm{kDa})$, apoferritin $(443 \mathrm{kDa})$. GDHs with the cut-off His-tag were used to determine molecular weights of the enzymes.

Assay of enzyme activities. GDH activity assay. The activity of GDH from Mtm. alcaliphilum was measured by recording the rate of $\mathrm{NAD}^{+}$or $\mathrm{NADP}^{+}$reduction at $30^{\circ} \mathrm{C} .1 \mathrm{~mL}$ of the reaction mixture routinely contained $50 \mathrm{mM}$ Glycine- $\mathrm{NaOH}$ buffer, $\mathrm{pH} 10.0 ; 0.3 \mathrm{mM} \mathrm{NAD}(\mathrm{P})^{+}$and $\sim 1 \mu \mathrm{g}$ of GDH. The reaction was started with $200 \mathrm{mM}$ D-glucose. The activity of $\mathrm{Mb}$. luteus GDH was measured using $20 \mathrm{mM}$ D-glucose in $50 \mathrm{mM}$ Tris$\mathrm{HCl}, \mathrm{pH}$ 8.5. Ribose, trehalose, deoxyglucose, galactose, fructose, arabinose, xylose, acetyl-glucosamine, maltose, sorbose, mannitol, mannose, sucrose, lactose and L-glucose at a final concentration of $10 \mathrm{mM}$ were tested as potential substrates for glucose dehydrogenases. The effect of $\mathrm{pH}$ on the activity was studied using the following buffers (50 mM): Glycine- $\mathrm{NaOH}$ (pH 9.0-10.5), CHES-NaOH (pH 8.5-10.0), Tris-HCl (pH 7.5-9.0), and MES- $\mathrm{NaOH}(\mathrm{pH} 5.0-7.0) . \mathrm{KCl}, \mathrm{NH}_{4} \mathrm{Cl}$ or $\mathrm{NaCl}$ at a final concentration of $50 \mathrm{mM}$ were added to test the effect of monovalent ions on the enzyme activity. The effects of divalent metals were assessed using $\mathrm{MgCl}_{2}, \mathrm{MnCl}_{2}, \mathrm{CoCl}_{2}$, $\mathrm{CuCl}_{2}, \mathrm{CdCl}_{2}, \mathrm{NiCl}_{2}$ or $\mathrm{ZnCl}_{2}$ at a final concentration of $1 \mathrm{mM}$. Glucose-6-phosphate, glucose-1-phosphate, fructose-6-phosphate, fructose-1,6-bisphosphate $(5 \mathrm{mM})$, pyruvate, PEP, oxaloacetate, lactate, malate, isocitrate, citrate, succinate, serine, $\alpha$-ketoglutarate, ATP, ADP, AMP and PPi $(1 \mathrm{mM})$ were examined as potential inhibitors or activators. To determine the optimal temperature for enzyme activity, the reaction was carried out in a temperature range of $10-70{ }^{\circ} \mathrm{C}$. To determine the apparent $K_{\mathrm{m}}$ values, substrate concentrations in the ranges of $0.391-400 \mathrm{mM}$ (glucose), $0.0078-1 \mathrm{mM}\left(\mathrm{NADP}^{+}\right), 0.0078-0.75 \mathrm{mM}\left(\mathrm{NAD}^{+}\right)$were used to measure the activity.

GntK activity assay. The activity of GntK was measured in the reaction mixture containing $50 \mathrm{mM}$ Tris- $\mathrm{HCl}$ buffer, pH 9.0; $8 \mathrm{mM} \mathrm{MgCl}$; $6 \mathrm{mM}$ gluconate; $5 \mathrm{mM} \mathrm{ATP;} 0.3 \mathrm{mM} \mathrm{NADP}^{+}$; $5 \mathrm{U}$ 6-phosphogluconate dehydrogenase (6PGDH, Sigma-Aldrich) as a coupling enzyme and $\sim 15 \mu \mathrm{g} \mathrm{GntK}$. The activity of Mb. luteus GntK was assayed in $50 \mathrm{mM}$ Tris- $\mathrm{HCl}$ buffer $(\mathrm{pH} \mathrm{8.0)}$. The reaction was started with $6 \mathrm{mM}$ sodium gluconate. To study the effect of $\mathrm{pH}$, the following buffers were used $(50 \mathrm{mM})$ : Carbonate $(\mathrm{pH} 9.0-10.5)$, TAPS- $\mathrm{NaOH}(\mathrm{pH}$ 8.0-9.0), Tris- $\mathrm{HCl}$ ( $\mathrm{pH} 7.5-9.0$ ), K-phosphate ( $\mathrm{pH} 7.0-8.0$ ), $\mathrm{MES}-\mathrm{NaOH}$ ( $\mathrm{pH} 5.0-6.0$ ) or citrate ( $\mathrm{pH} 4.0-5.0$ ). Glucose 6-phosphate, glucose 1-phosphate, 6-phosphogluconate, PEP, ADP (5 mM at the final concentration), AMP $(4 \mathrm{mM})$, pyruvate $(3 \mathrm{mM}), \operatorname{PPi}(2 \mathrm{mM})$, oxaloacetate and $\alpha$-ketoglutarate $(1 \mathrm{mM})$ were tested as potential inhibitors or activators. To determine the apparent $K_{\mathrm{m}}$, the activity was measured in the concentration ranges of 0.031-8 mM gluconate and 0.015-4 mM ATP. The NAD $/ \mathrm{NADP}^{+}$reduction rates were measured at $340 \mathrm{~nm}$ with a UV-1700 spectrophotometer (Shimadzu). The apparent $K_{\mathrm{m}}$ and $V_{\max }$ values were calculated using Sigma Plot (version 10). The exponentially grown cells were used to measure enzymatic activity in cell-free extracts.

Mutant generation. The strains of Mtm. alcaliphilum with the double $g d h / g l k$ and gntk/glk gene mutations were generated by insertion mutagenesis. Intergenic regions flanking the $g d h$ gene were amplified from DNA using primers dGDH2_f1/dGDH2_r1 and dGDH2_f2/dGDHr (Supplementary Table S6) and cloned in the pCM184 vector at the BglII/Acc65I and SacII/SacI sites. The resulting vector pCM184:gdhKm was introduced into Mtm. alcaliphilum cells by electroporation ${ }^{36}$. The $g d h^{-}$clones were selected by PCR using primers dGDH2_f1 and dGDHr.

The gntk-gnl DNA locus was amplified by PCR using primers dGnKinF and dGnKinR (Supplementary Table S6) containing the recognition sites for restriction endonucleases EcoRI and MluI and inserted into pCM184 with removal of the kanamycin resistance gene. The middle of this locus was removed at the sites of endonuclease PvuI and replaced by the kanamycin resistance gene. The kanamycin resistance gene was amplified by PCR from pCM184. The resulting plasmid pCM184:gntk-Km was introduced into Mtm. alcaliphilum cells by electroporation.

To obtain double $g d h^{-} / g l k^{-}$or $g n t k^{-} / g l k^{-}$mutant strains, the previously generated plasmid pCM184:glkGm ${ }^{8}$ was introduced into either $g d h^{-}$or $g n t k^{-}$strain by electroporation. The $g l k^{-}$clones were selected by PCR using primers dGlk (Acc65I) and dGlk (SacII) (Supplementary Table S6). The $g d h^{-} / g l k^{-}$and $g n t k^{-} / g l k^{-}$strains were selected on methanol plates with $\mathrm{Km}(100 \mu \mathrm{g} / \mathrm{mL})$ and $\mathrm{Gm}(10 \mu \mathrm{g} / \mathrm{mL})$.

Isolation and analysis of carbohydrates. Carbohydrates were analyzed in cells of Mtm. alcaliphilum grown up to the late exponential phase in $750 \mathrm{ml}$ flasks containing $200 \mathrm{~mL}$ of mineral salt medium at stirring. Cells of the WT strain grown under methane were collected at the optical density $\mathrm{OD}_{600}=0.84-0.92$ (which was equivalent 53-57 mg DCW), cells of gntk $/$ glk $^{-}$mutant at $\mathrm{OD}_{600}=0.6-0.7(42-45 \mathrm{mg} \mathrm{DCW})$ and for $g d h^{-} / g l k^{-}$mutant at $\mathrm{OD}_{600}=0.61-0.68(40-43 \mathrm{mg}$ DCW $)$. The WT strain grown on methanol was harvested up to $\mathrm{OD}_{600}=0.91-0.93$ (which was equivalent to $57-60 \mathrm{mg} \mathrm{DCW}$ ), cells of the gntk $/ \mathrm{glk}^{-}$mutant to $\mathrm{OD}_{600}=0.66-$ 0.78 (43-47 mg DCW) and $g d h^{-} / g l k^{-}$strain to $\mathrm{OD}_{600}=0.66-0.68$ (41-43 mg DCW). The freeze-dried cells (30$50 \mathrm{mg}$ ) were used for carbohydrate extraction by $80 \%$ methanol as described ${ }^{8}$. The dried methanol extract was dissolved in $540 \mu \mathrm{L} \mathrm{H}_{2} \mathrm{O}$ followed by the addition of $60 \mu \mathrm{L} 4 \mathrm{M}$ solution of 3-trimethylsilyl [2,2,3,3-2H4] propionate (TSP) in $\mathrm{D}_{2} \mathrm{O}$ mixing in a shaker for $30 \mathrm{~s}$ and centrifuged at $15,000 \mathrm{~g}$ for $5 \mathrm{~min}$. The spectra were recorded with an AVANCE III 600 NMR spectrometer (Bruker) at an operating frequency of $600 \mathrm{MHz}$, at $298 \mathrm{~K}$, with a spectral width of $24 \mathrm{ppm}$ and 90 -degree pulse of $12.5 \mu \mathrm{s}$. The number of acquisitions was $128 \mathrm{scans}$; the interval between the scans was $10 \mathrm{~s}$; free induction decay (FID) was recorded for $96 \mathrm{k}$ points over $3.42 \mathrm{~s}$. For correct signal assignment, both spectra acquired in the 1D and 2D COSY NMR experiments were analyzed. The data were 
confirmed using the AMIX spectral software database (Bruker), as well as the Biological Magnetic Resonance Data Bank internet-based collection.

The concentration of glucose 1-phosphate $(\delta 5.46, \mathrm{~m}, 1 \mathrm{H})$, glucose 6-phosphate $(\delta 5.37, \mathrm{~m}, 1 \mathrm{H})$, trehalose $\left(\delta 5.20, \mathrm{~d}, \mathrm{~J}=3.8 \mathrm{~Hz}, 1 \mathrm{H}, 1^{\prime} \mathrm{H}\right)$, maltose derivative/maltotriose $\left(\delta 5.41\right.$, br $\left.1,1^{\prime} \mathrm{CH}\right)$, glucose $(\delta 5.24, \mathrm{~d}, \mathrm{~J}=3.8 \mathrm{~Hz}$, $1 \mathrm{H})$, sucrose $(\delta 5.42, \mathrm{~d}, \mathrm{~J}=3.8 \mathrm{~Hz}, 1 \mathrm{H})$ were measured by using $\mathrm{H}^{1} \mathrm{NMR}$. The sucrose and glucose contents were additionally measured using anthron reagent ${ }^{8}$ and ABTS assay ${ }^{37}$. Analytical and NMR data for sucrose and glucose are practically coincided; Table 3 shows the data obtained by analytical methods.

The concentration of gluconate in methanol extract was determined using GntK from Mb. luteus (the present work). In brief, the reaction mixture $(1 \mathrm{~mL})$ contained $50 \mathrm{mM}$ Tris- $\mathrm{HCl}$ buffer ( $\mathrm{pH} 9.0), 10 \mathrm{mM} \mathrm{MgCl}, 2 \mathrm{mM}$ ATP, $0.3 \mathrm{mM} \mathrm{NADP}^{+}$, 5U 6PGDH, $10 \mathrm{U}$ His-tagged GntK from $M b$. luteus and 5-25 $\mu \mathrm{L}$ methanol extract. After 3-min incubation, $\mathrm{OD}_{340}$ was measured. To build the calibration curve, gluconate concentrations in the range of $2.925-23.4 \mu \mathrm{g} / \mathrm{mL}$ were used.

Glycogen was extracted from $20 \mathrm{mg}$ of freeze-dried cells as described ${ }^{31}$. The glycogen content was estimated using "Glycogen Assay kit" according to the manufacturer's recommendations.

Analysis of the promoter activity of the gntk and amy genes. Using primer pairs PamyF/PamyR or PglnF/PglnR (Supplementary Table S6) the PCR products of 563 and 551 bp containing the sequences of putative amy or gntk promoters, respectively, were obtained. The PCR product with the cat gene was generated with primers SDglnK $+\mathrm{CmF} / \mathrm{CmR}$ using plasmid p34S-Cm as the source of the cat gene. Primers PamyF/PglnF and $\mathrm{CmR}$ are tailed with $\mathrm{XbaI}$ and SphI restriction ends, respectively. PamyR/PglnR is tailed with a 20 bp sequence homologous to the first $20 \mathrm{bp}$ of SDglnK $+\mathrm{CmF}$ containing the SD sequence of the gntK gene. PCR products containing the amy or the gntk promoter and the cat gene were used as a template in the third PCR reaction to produce the final fusion PCR products Pamy-cat or Pgntk-cat with XbaI and SphI restriction ends. The plasmid pMHA200 (Supplementary Table S5) was digested with these endonucleases to remove a 752-bp segment, which was replaced by the Pamy-cat or Pgntk-cat fragments of DNA. The correct assembly was verified by sequencing, and the new plasmids were designated as pMHA200:Pamy-cat and pMHA200:Pgntk-cat. The resulting plasmids were introduced into Mtm. alcaliphilum cells by electroporation.

The activity of chloramphenicol acetyltransferase (i.e. catalyzis the reaction of the acyl group transfer from acetyl-CoA to chloramphenicol) was assessed by recording the 5-thio-2-benzoic acid accumulation as a result of interaction between 5,5'-dithiobis-(2-nitrobenzoic acid) (DTNB) and CoASH sulfhydryl groups at $30^{\circ} \mathrm{C}$. The reaction mixture $(1 \mathrm{~mL}$ ) contained $50 \mathrm{mM}$ Tris-HCl buffer ( $\mathrm{pH} 7.5), 0.1 \mathrm{mM}$ DTNB, $1 \mathrm{mM}$ acetyl CoA, and $10-50 \mu \mathrm{L}$ cell-free extract of the Mtm. alcaliphilum. The reaction was triggered by $2 \mathrm{mM}$ chloramphenicol. The optical density was measured at $412 \mathrm{~nm}$. The Mtm. alcaliphilum pMHA:cat and WT strains lacked the activity of chloramphenicol acetyltransferase.

Received: 13 January 2021; Accepted: 6 April 2021

Published online: 22 April 2021

\section{References}

1. Hanson, R. S. \& Hanson, T. E. Methanotrophic bacteria. Microbiol. Rev. 60, 439-471 (1996).

2. Khmelenina, V. N., Murrell, J. C., Smith, T. J. \& Trotsenko, Y. A. Physiology and biochemistry of the aerobic methanotrophs. In Aerobic Utilization of Hydrocarbons, Oils and Lipids. Handbook of Hydrocarbon and Lipid Microbiology (ed. Rojo, F.) 1-25 (Springer, 2018).

3. Dedysh, S. N., Knief, K. \& Dunfield, P. F. Methylocella species are facultatively methanotrophic. J. Bacteriol. 187, 4665-4670 (2005).

4. Rozova, O. N., Khmelenina, V. N., Gavletdinova, J. Z., Mustakhimov, I. I. \& Trotsenko, Y. A. Acetate kinase - an enzyme of the postulated phosphoketolase pathway in Methylomicrobium alcaliphilum 20Z. Ant. Leeuwenhoek. 108, 965-974 (2015).

5. Kalyuzhnaya, M. G. et al. Highly efficient methane biocatalysis revealed in methanotrophic bacterium. Nat. Commun. 4, 2785. https://doi.org/10.1038/ncomms3785 (2013).

6. Khmelenina, V. N., But, S. Y., Rozova, O. N. \& Trotsenko, Y. A. Metabolic features of aerobic methanotrophs: news and views. Curr. Issues Mol. Biol. 33, 85-100 (2019).

7. But, S. Y., Rozova, O. N., Khmelenina, V. N., Reshetnikov, A. S. \& Trotsenko, Y. A. Properties of recombinant ATP-dependent fructokinase from the halotolerant methanotroph Methylomicrobium alcaliphilum 20Z. Biochemistry (Mosc.) 77, 372-377 (2012).

8. Mustakhimov, I. I. et al. The properties and potential metabolic role of glucokinase in halotolerant obligate methanotroph Methylomicrobium alcaliphilum 20Z. Ant Leeuwenhoek. 110, 375-386 (2017).

9. Reshetnikov, A. S. et al. ATP- and polyphosphate-dependent glucokinases from aerobic methanotrophs. Microorganisms 7, E52. https://doi.org/10.3390/microorganisms7020052 (2019).

10. Nishiya, Y., Tamura, N. \& Tamura, T. Analysis of bacterial glucose dehydrogenase homologs from thermoacidophilic archaeon Thermoplasma acidophilum: finding and characterization of aldohexose dehydrogenase. Biosci. Biotechnol. Biochem. 68, 2451-2456 (2004).

11. Rossmann, M. G. \& Argos, P. Exploring structural homology of proteins. J. Mol. Biol. 105, 75-95 (1976).

12. Yamamoto, K. et al. Crystal structure of glucose dehydrogenase from Bacillus megaterium IWG3 at 17A resolution. J. Biochem. 129, 303-312 (2001)

13. del Castillo, T. et al. Convergent peripheral pathways catalyze initial glucose catabolism in Pseudomonas putida: genomic and flux analysis. J. Bacteriol. 189, 5142-5152 (2007).

14. Verhees, C. H. et al. The unique features of glycolytic pathways in Archaea. Biochem. J. 375, 231-246 (2003).

15. Chen, X. et al. The Entner-Doudoroff pathway is an overlooked glycolytic route in cyanobacteria and plants. PNAS 113, 5441-5446 (2016).

16. Makowka, A. et al. Glycolytic shunts replenish the calvin-benson-bassham cycle as anaplerotic reactions in cyanobacteria. Mol. Plant. 13, 471-482 (2020).

17. Hyun, J., Abigail, M., Choo, J. W., Ryu, J. \& Kim, H. K. Effects of N-/C-terminal extra tags on the optimal reaction conditions, activity, and quaternary structure of Bacillus thuringiensis glucose 1-dehydrogenase. J. Microbiol. Biotechnol. 26, 1708-1716 (2016). 
18. Ding, H., Gao, F., Yu, Y. \& Chen, B. Biochemical and computational insights on a novel acid-resistant and thermal-stable glucose 1-dehydrogenase. Int. J. Mol. Sci. 18, E1198. https://doi.org/10.3390/ijms18061198 (2017).

19. Mitamura, T., Urabe, I. \& Okada, H. Enzymatic properties of isoenzymes and variants of glucose dehydrogenase from Bacillus megaterium. Eur. J. Biochem. 186, 389-393 (1989).

20. Fujita, Y., Ramaley, R. \& Fresse, E. Location and properties of glucose dehydrogenase in sporulating cells and spores of Bacillus subtilis. J. Bacteriol. 132, 282-293 (1977).

21. Ding, H.-T. et al. Cloning and expression in E. coli of an organic solvent-tolerant and alkali-resistant glucose 1-dehydrogenase from Lysinibacillus sphaericus G10. Bioresource Technol. 102, 1528-1536 (2011).

22. Tamura, K., Dudley, J., Nei, M. \& Kumar, S. MEGA4: molecular evolutionary genetics analysis (MEGA) software version 4.0. Mol. Biol. Evol. 24, 1596-1599 (2007).

23. Siebers, B., Wendisch, V. F. \& Hensel, R. Carbohydrate metabolism in Thermoproteus tenax: in vivo utilization of the non-phosphorylative Entner-Doudoroff pathway and characterization of its first enzyme, glucose dehydrogenase. Arch. Microbiol. 168, $120-127$ (1997).

24. Basner, A. \& Antranikian, G. Isolation and biochemical characterization of a glucose dehydrogenase from a hay infusion metagenome. PLoS ONE 9, e85844. https://doi.org/10.1371/journal.pone.0085844 (2014).

25. Pongtharangkul, T. et al. Kinetic properties and stability of glucose dehydrogenase from Bacillus amyloliquefaciens SB5 and its potential for cofactor regeneration. AMB Expr. 5, 68. https://doi.org/10.1186/s13568-015-0157-9 (2015).

26. De Smet, K. A., Weston, A., Brown, I. N., Young, D. B. \& Robertson, B. D. Three pathways for trehalose biosynthesis in mycobacteria. Microbiology 146, 199-208 (2000).

27. Park, J.-T. et al. Role of maltose enzymes in glycogen synthesis by Escherichia coli. J. Bacteriol. 193, 2517-2526 (2011).

28. Seibold, G. M., Wurst, M. \& Eikmanns, B. J. Roles of maltodextrin and glycogen phosphorylases in maltose utilization and glycogen metabolism in Corynebacterium glutamicum. Microbiology 155, 347-358 (2009).

29. Clermont, L. et al. The $\alpha$-glucan phosphorylase MalP of Corynebacterium glutamicum is subject to transcriptional regulation and competitive inhibition by ADP-glucose. J. Bacteriol. 197, 1394-1407 (2015).

30. Zhu, Y. B., Chen, X., Chen, T., Shi, S. B. \& Zhao, X. M. Over-expression of glucose dehydrogenase improves cell growth and riboflavin production in Bacillus subtilis. Biotechnol. Lett. 28, 1667-1672 (2006).

31. Linton, J. D. \& Crisp, R. E. The occurrence and identification of intracellular polyglucose storage granules in Methylococcus NCIB 11083 grown in chemostat culture on methane. Arch. Microbiol. 117, 41-48 (1978).

32. But, SYu., Dedysh, S. N., Popov, V. O., Pimenov, N. V. \& Khmelenina, V. N. Construction of a type-I metanotroph with reduced capacity for glycogen and sucrose accumulation. Appl. Biochem. Microbiol. (Moscow) 56, 538-543 (2020).

33. Reiser, K. M. Nonenzymatic glycation of collagen in aging and diabetes. Proc. Soc. Exp. Biol. Med. 218, 23-37 (1998).

34. Khmelenina, V. N. et al. Osmoadaptation in halophilic and alkaliphilic methanotrophs. Arch. Microbiol. 172, 321-329 (1999).

35. Reshetnikov, A. S. et al. Characterization of the pyrophosphate-dependent 6-phosphofructokinase from Methylococcus capsulatus Bath. FEMS Microbiol. Lett. 288, 202-210 (2008).

36. Yan, X., Chu, F., Puri, A. W., Fu, Y. \& Lidstrom, M. E. Electroporation-based genetic manipulation in type I methanotrophs. Appl. Environ. Microbiol. 82, 2062-2069. https://doi.org/10.1128/AEM.03724-15 (2016).

37. Yee, Y. C., Hashim, R., Yahya, A. R. M. \& Bustami, Y. Colorimetric analysis of glucose oxidase-magnetic cellulose nanocrystals (CNCs) for glucose detection. Sensors (Basel) 19, 2511. https://doi.org/10.3390/s19112511 (2019).

\section{Acknowledgements}

This work was supported by the Russian Foundation for Basic Research (project No. 18-04-00728A).

\section{Author contributions}

All authors contributed to the study conception and design. Material preparation, data collection and analysis were performed by O.N.R, A.S.R. and I.I.M. The first draft of the manuscript was written by V.N.K.; all authors commented on the previous versions of the manuscript. All authors have read and approved the final manuscript.

\section{Competing interests}

The authors declare no competing interests.

\section{Additional information}

Supplementary Information The online version contains supplementary material available at https://doi.org/ 10.1038/s41598-021-88202-x.

Correspondence and requests for materials should be addressed to V.N.K.

Reprints and permissions information is available at www.nature.com/reprints.

Publisher's note Springer Nature remains neutral with regard to jurisdictional claims in published maps and institutional affiliations.

Open Access This article is licensed under a Creative Commons Attribution 4.0 International License, which permits use, sharing, adaptation, distribution and reproduction in any medium or format, as long as you give appropriate credit to the original author(s) and the source, provide a link to the Creative Commons licence, and indicate if changes were made. The images or other third party material in this article are included in the article's Creative Commons licence, unless indicated otherwise in a credit line to the material. If material is not included in the article's Creative Commons licence and your intended use is not permitted by statutory regulation or exceeds the permitted use, you will need to obtain permission directly from the copyright holder. To view a copy of this licence, visit http://creativecommons.org/licenses/by/4.0/.

(c) The Author(s) 2021 